\title{
Evaluation of quality characteristics in commercial yogurt
}

\author{
Kwang-Seup Shin, Jeung-Hee Lee* \\ Department of Food and Nutrition, Daegu University, Gyeongsan 38453, Korea
}

\section{시중 유통되는 요구르트의 품질특성 평가}

\author{
신광섭 · 이정희 ${ }^{*}$ \\ 대구대학교 식품영양학과
}

\begin{abstract}
Commercial yogurt can be classified as fermented milk (FM) and condensed fermented milk (CFM). A selection of commercial yogurt was collected from domestic markets and the quality characteristics were compared by analyzing total acidity, viscosity, organic acids, sugars, conjugated linoleic acid (CLA), and aroma pattem. Total acidity and viscosity in FM were significantly lower than those in CFM $(\mathbf{p}<0.05)$. The major organic acid of commercial yogurt was lactic acid, the content of which was 8.15-4.72 times and 26.83-47.20 times higher than that of citric acid and acetic acid, respectively. CFM contained 1.47 times more lactic acid and 2.53 times more citric acid than FM. The total sugar content in FM was two times higher than that in CFM and the major sugars measured were sucrose, lactose, glucose, and maltose. The sucrose content was the highest in FM. CFM contained 23.65 times more CLA and 10.81 times more lipid than FM. The aroma patterns of yogurt analyzed with an electronic nose were clustered into Therefore, among commercial yogurt, CFM had higher viscosity, organic acid and CLA content, but lower sugar content than FM, which resulted in a relatively strong sour and weak sweet taste.
\end{abstract}

Key words : aroma pattem, CLA, organic acid, sugar, yogurt

\section{서 론}

발효 유제품인 요구르트는 원유 또는 유가공품을 유산 균으로 발효시키고 산미와 감미를 강화시킨 것으로 주원료 인 우유의 성분과 유산균의 작용으로 생성된 lactic acid, peptone, peptides, oligosaccharides 등으로 인해 영양과 소화 율이 높은 식품이다 $(1,2)$. 요구르트의 섭취에 따른 유당불 내증 감소, Bifidobacteria 등의 유익균 증가, 장내부패 억제 와 변비개선 등의 정장효과, 항암 및 혈중 cholesterol 저하 효과 등이 알려져 있다(3). 주요 유산균으로 Lactobacillus bulgaricus, L. acidophilus, L. casei, Streptococcus thermophilus가 사용된다(3). 요구르트는 식품공전상 발효 유로 분류되며 그중 발효유는 무지유고형분과 유산균수가

*Corresponding author. E-mail : jeunghlee@daegu.ac.kr Phone : 82-53-850-6836, Fax : 82-53-850-6839

Received 22 February 2018; Revised 28 March 2018; Accepted 29 March 2018.

Copyright (c) The Korean Society of Food Preservation. All rights reserved.
각각 $3 \%$ 와 $10^{7} / \mathrm{mL}$ 이상, 농후발효유는 무지유고형분 $8 \%$ 이상인 호상 또는 액상의 형태로서 유산균수 $10^{8} / \mathrm{mL}$ 이상 의 것을 의미한다(4).

요구르트는 유당, 단백질, 지방, 비타민 $\left(\mathrm{A}, \mathrm{B}_{1}, \mathrm{~B}_{2}, \mathrm{~B}_{12}\right.$, niacin, 엽산), 미네랄(칼슘, 인, 마그네슘, 아연) 등을 함유한 다. 발효과정 중 유당은 유산균에 의해 포도당과 갈락토오 스로 분해되고, 비타민은 원유의 종류와 발효조건, 제조방 법 등에 따라 함량의 차이가 있을 수 있지만 미네랄의 함량 변화는 거의 없다(5). 또한 발효과정 중 대사산물로 소량의 카르보닐화합물(acetaldehyde, diacetyl, acetoin, acetone 등), 휘발성 지방산(malic acid, acetic acid, propionic acid, butyric acid, caproic acid, caprylic acid 등), 아미노산 및 ethanol이 생성되어 요구르트의 맛과 향기에 영향을 미친다(3).

요구르트에 함유된 당과 유기산은 물리화학적 및 관능적 품질에 영향을 준다. 요구르트의 주요 유기산은 acetic, citric, formic, lactic, succinic, propionic acids 등이고, 주요 당은 원유의 lactose와 lactose 분해산물인 glucose, galactose(5), 제조 시 첨가된 fructose와 sucrose 등이다(6). 
유산균은 발효과정 중 원유의 당을 이용해 유기산을 생성하 는데 그 중 대표적인 것이 lactose에서 생성된 lactic acid이 며, 이때 생성된 유기산으로 $\mathrm{pH}$ 가 저하되고 이는 요구르트 의 맛과 양의 상관관계를 가진다고 알려져 있다(7). 요구르 트에 함유된 conjugated linoleic acid(CLA)는 linoleic $\operatorname{acid}(\mathrm{LA})$ 의 위치 및 기하 이성질체들의 혼합물로서 공액이 중결합을 가지며, LA가 반추동물의 rumen bacteria에 의해 biohydrogenation되는 과정 중에 생성된다. CLA 이성질체 들 중 인체에서 생리활성을 나타내는 이성질체는 주로 cis-9,trans-11 CLA와 trans-10,cis-12 CLA이고, 항암(8). 항 동맥경화(9), 체지방 감소(10), 면역력 증진(11) 등의 효과를 인정받고 있다. CLA는 유제품인 우유, 요구르트, 치즈, 버 터에 함유되어 있으며, 그중 cis-9,trans-11 CLA가 총 CLA 이성질체들의 약 $80-95 \%$ 를 차지한다(12).

기능성 식품 소재(삼백초, 통보릿가루, 배양인삼, 오디분 말, 미강 등)를 첨가한 요구르트의 적정 발효시간과 저장기 간 중의 품질변화와 소비자의 기호도를 조사한 선행연구에 서(1,2,13-15), 삼백초와 배양인삼을 각각 첨가하여 제조된 요구르트가 유산균 수와 산 생성량이 높고, 삼백초 $0.4 \%$ 또는 배양인삼 0.5-1.0\%의 첨가량이 전체적인 기호도 측면 에서 우수하다고 보고하였다 $(1,13)$. 또한, 시판 요구르트의 품질 평가 연구에서는 CLA 함량 및 저장기간 동안 $\mathrm{pH}$, 산도, Brix, 젖산균의 변화를 조사하였다 $(16,17)$.

근래 요구르트 제품 시장은 복합유산균 이용, 천연과즙 첨가, 면역력강화 등의 기능성을 부여한 웰빙 트렌드를 기 반으로 하며, 유제품시장의 전반적인 감소세 가운데서도 상대적으로 선전하고 있다. 그러나 요구르트의 높은 당함 량은 비만, 고혈압, 당뇨 등의 만성질환 발생 가능성을 높이 고, 낮은 $\mathrm{pH}$ 는 치아부식에 영향을 줄 수 있다 $(18,19)$. 또한, 우리나라 국민의 당류섭취량은 지속적인 증가 추세에 있 고, 특히 어린이·청소년·청년층의 가공식품을 통한 당류 섭취량은 적정섭취기준을 초과하였으며, 그 중 음료류를 통한 당류 섭취 비율은 2007년 14.6\%에서 2013년 19.3\%으 로 증가하였다(18). 따라서 식품의약품안전처는 우리나라 국민의 당류 적정섭취를 유도하기 위해 2016년도부터 당류 저감정책을 추진하여 당류 줄이기 캠페인 및 식품업계와 연계한 저당함유 가공식품개발 지원 등 선제적이고 체계적 인 관리를 하고 있다(18).

본 연구에서는 소비자의 수요가 지속적으로 증가하고 있는 요구르트 제품을 대상으로 당 및 유기산의 함량과 품질 특성을 평가하여 소비자들의 구매 선택을 위한 기본 자료로 제공하고자 한다. 따라서 시중 유통되어 판매되는 요구르트 제품 중 구매율이 높은 발효유와 농후발효유를 수거하여 당, 유기산 및 CLA 함유량과, $\mathrm{pH}$, 총산도, 점도를 측정하여 물리화학적 특성을 조사하였고, 요구르트의 향기 성분을 전자코로 분석하여 향기패턴을 평가하였다.

\section{재료 및 방법}

실험 재료

국내 시중에 유통되는 요구르트인 액상발효유 8종, 액상 농후발효유 9종을 인근 대형 할인매장에서 구입하여 냉장 보관하며 실험에 사용하였다. 유기산 표준물질(malic, citric, lactic, acetic, formic acid)과 당 표준물질(fructose, glucose, sucrose, lactose, maltose)은 Sigma-Aldrich Chemical Co., Ltd.(St. Louis, MO, USA)에서 구입하였고 water와 acetonitrile은 HPLC-grade(Sigma-Aldrich Chemical Co., Ltd.)을 사용하였다. 표준물질인 conjugated linoleic $\operatorname{acid}($ cis-9,trans-11)과 triundecanoin은 각각 Sigma-Aldrich Chemical Co. 와 NU-CHEK PREP, Inc.(Elysian, MN, USA) 에서 구입하였다.

\section{$\mathrm{pH}$ 및 총산 분석}

요구르트의 $\mathrm{pH}$ 는 $\mathrm{pH}$ meter(Orion $420 \mathrm{~A}+$, Thermo electron Co., Beverly, MA, USA)를 사용하여 측정하였다. 요구르트의 총산은 phenolphthalein 지시약을 이용한 $\mathrm{AOAC}$ 방법으로 분석하였다(20). 끓여서 식힌 증류수 200 $\mathrm{mL}$ 에 $1 \%$ phenolphthalein $1 \mathrm{~mL}$ 를 첨가한 후 시료 $5 \mathrm{~mL}$ 를 넣고 담홍색(적정종말점)이 될 때까지 $0.1 \mathrm{~N} \mathrm{NaOH}$ 용액으 로 적정한 후 총산함량을 $\mathrm{g}$ of lactic acid/100 mL yogurt으로 구하였다(20).

\section{탁도 및 점도 분석}

발효유의 탁도는 UV/VIS Spectrophotometer(Optizen 2120UV, Mecasys Co., Ltd., Daejeon, Korea)를 이용해 600 $\mathrm{nm}$ 에서 흡광도를 측정하였으며, 탁도가 높은 시료는 증류 수로 희석하여 사용하고, 측정값에 희석배수를 곱하여 구 하였다. 점도는 Brookfield digital viscometer(RVTD, Brookfield Engineering labs. INC. Stoughtion, MA, USA)에 Spindle no.2를 장착하여, 시료 $(100 \mathrm{~mL})$ 를 $100 \mathrm{rpm}$ 에서 3반 복 측정한 후, 측정값에 $\mathrm{RV}$ spindle factor 값을 곱하여 viscosity in centipoise $(\mathrm{mPa} \cdot \mathrm{s})$ 로 구하였다.

\section{$\mathrm{HPLC}$ 를 이용한 유기산 분석}

발효유와 농후발효유를 증류수로 각각 10 배와 4 배로 희 석하고 원심분리 $(3,880 \times \mathrm{g}, 5 \mathrm{~min})$ 한 후 상층액을 분리하여 syringe filter(NY syringe filter, $0.22 \mu \mathrm{L}, 13 \mathrm{~mm}$, Hanguk science Co., Ltd., Daejeon, Korea)로 여과한 후 시료로 사용 하였다. 유기산 분석은 high performance liquid chromatography (HPLC, Young Lin instrument Co. Anyang, Korea)에 RSpak $\mathrm{KC}-\mathrm{G} 8 \mathrm{~B}\left(8.0 \mathrm{~mm}\right.$ I.D $\times 50 \mathrm{~mm}$, Shodex ${ }^{\mathrm{TM}}$, Tokyo, Japan)과 RSpak KC-811(8.0 mm I.D $\times 300$ mm, Shodex ${ }^{\mathrm{TM}}$, Tokyo, Japan)의 2 개의 column을 연결하여 실시하였다. 검출기는 $\mathrm{UV} / \mathrm{Vis}$ detector$(440 \mathrm{~nm})$, 이동상은 $3.0 \mathrm{mM} \mathrm{HClO}{ }_{4}(1$ 
$\mathrm{mL} / \mathrm{min}$ ), 반응지시약은 $0.2 \mathrm{mM}$ bromothymol blue 용액(1 $\mathrm{mL} / \mathrm{min}$ )으로 설정하였고 column oven 온도는 $63^{\circ} \mathrm{C}$ 로 유지 하고, 시료는 $20 \mu \mathrm{L}$ 를 주입하였다. 표준물질(malic, citric, lactic, acetic, formic acids)로 농도별 표준용액을 제조하여 검량선을 작성한 후 요구르트에 함유된 유기산의 함량을 $\mathrm{mg} / \mathrm{g}$ 으로 구하였다.

\section{HPLC를 이용한 당 분석}

요구르트의 당 분석은 식품의약품안전처의 일반성분분 석법에 의거하여 실시하였다(4). 요구르트 $5 \mathrm{~g}$ 에 증류수 $25 \mathrm{~mL}$ 를 첨가하여 2분간 혼합한 후 시료로 사용하였다. 당 분석을 위해 Asahipak $\mathrm{NH}_{2}$ P-50 4E column(4.6 mm I.D $\times 250 \mathrm{~mm}$, Shodex ${ }^{\mathrm{TM}}$, Tokyo, Japan)과 Refractive Index Detector(Younglin instrument Co., Anyang, Korea) 를 장착 한 HPLC을 사용하였으며, 이동상은 acetonitrile:water (75:25, v/v), 유속은 $1 \mathrm{~mL} / \mathrm{min}$, column oven 온도는 $35^{\circ} \mathrm{C}$, 시료 주입량은 $20 \mu \mathrm{L}$ 로 설정하였다. 표준물질(fructose, glucose, sucrose, lactose, maltose)로 농도별 표준용액을 제 조하여 검량선을 작성한 후 발효유에 함유된 당의 함량을 구하여 $\mathrm{mg} / \mathrm{g}$ 으로 나타내었다.

지방 추출 및 conjugated linoleic acid(CLA) 분석

요구르트 $(10 \mathrm{~g})$ 에 folch 용액(chloroform:methanol, 2:1, v/v) $20 \mathrm{~mL}$ 를 넣어 혼합한 후 shaking water bath(LSB-045S, DAIHAN LabTech Co., Ltd., Namyangju-city, Korea) $\left(50^{\circ} \mathrm{C}\right.$, $190 \mathrm{rpm}$ )에서 30분 동안 지방을 추출하였다. 원심분리 $(1,940 \times \mathrm{g}, 5 \mathrm{~min})$ 후 하층액을 분리하고 $\mathrm{N}_{2}$ 으로 용매를 제거하였다. 시험관에 추출된 지방 $50 \mathrm{mg}$, internal standard (triundecanoin, $5 \mathrm{mg} / \mathrm{mL}$ isooctane) $1 \mathrm{~mL}, 0.5 \mathrm{~N}$ methanolic $\mathrm{NaOH} 1.5 \mathrm{~mL}$ 를 넣고 $85^{\circ} \mathrm{C}$ water bath에서 10 분간 반응시킨 후 냉각하고, $12 \%$ boron trifluoride in methanol $2 \mathrm{~mL}$ 를 첨가 하여 $85^{\circ} \mathrm{C}$ 에서 10 분간 methylation하였다. 냉각 후 isooctane $2 \mathrm{~mL}$, 포화 $\mathrm{NaCl}$ 용액 $1 \mathrm{~mL}$ 를 첨가하고 1 분간 교반한 후 원심분리 $(3,233 \times \mathrm{g}, 5 \mathrm{~min})$ 하고, 상층액을 취하여 CLA 분석 을 위한 시료로 사용하였다. $\mathrm{SP}^{\mathrm{TM}}-2560$ column(100 m×0.25 $\mathrm{mm}, 0.2 \mu \mathrm{m}$ film thickness, Supelco, Bellefonte, PA, USA)과 불꽃이온화검출기가 장착된 gas chromatography(GC-2010 Plus, SHIMADZU Corp., Kyoto, Japan)을 사용하고, column flow는 $1 \mathrm{~mL} / \mathrm{min}(\mathrm{N} 2)$, split ratio는 100:1 으로 설정하였다. 주입기와 검출기의 온도는 각각 $250^{\circ} \mathrm{C}$ 와 $260^{\circ} \mathrm{C}$ 로 설정하고, column oven은 $100^{\circ} \mathrm{C}$ 에서 5 분간 유지한 후 $4^{\circ} \mathrm{C} / \mathrm{min}$ 으로 $240^{\circ} \mathrm{C}$ 까지 승온하고 40 분간 유지하였다. 시료 $1 \mu \mathrm{L}$ 를 $\mathrm{GC}$ 주입기에 주입하여 얻은 크로마토그램과 표준물질인 cis-9, trans-11 CLA의 retention time과 비교하여 동정한 후 식품공 전방법에 의거하여 요구르트에 함유된 CLA함량을 구하였 다(4).
전자코를 이용한 향기패턴분석

전자코는 metal oxide sensor(SY/G, SY/AA, SY/Gh, $\mathrm{SY} / \mathrm{gCT1}, \mathrm{T} 30 / 1, \mathrm{P} 10 / 1, \mathrm{P} 10 / 2, \mathrm{P} 40 / 1, \mathrm{~T} 70 / 2, \mathrm{PA} 2)$ 로 구성된 alpha-FOX 3000 Electronic Nose System(Alpha MOS, Toulouse, France)을 이용하였다. 전자코 분석조건은 온도 $36^{\circ} \mathrm{C}$, 압력 $5 \mathrm{psi}$, air flow $150 \mathrm{~mL} / \mathrm{min}$ 으로 설정하였다. 향기 분석을 위해 요구르트 $10 \mathrm{~g}$ 을 $20 \mathrm{~mL}$ vial에 담고 $35^{\circ} \mathrm{C}$ 에서 4분간 $500 \mathrm{rpm}$ 으로 incubation한 후 headspace에 포집된 향 기성분 $(2,500 \mu \mathrm{L})$ 을 syringe $\left(45^{\circ} \mathrm{C}\right)$ 에 담아 $0.5 \mathrm{~mL} / \mathrm{sec}$ 속도로 injection port에 주입하였다. 전자코 센서의 안정화를 위해 분석시료들 간의 간격은 30 분으로 설정하였다. 전자코 분 석 결과 얻은 각 센서의 감응도(delta $\mathrm{R}_{\mathrm{gas}} / \mathrm{R}_{\mathrm{air}}$ )을 SPSS 프로 그램(Statistical Package for the Social Sciences, Ver. 24, SPSS Inc., Chicago, IL, USA)의 주성분분석(principal component analysis, $\mathrm{PCA}$ )을 실시하여 제 1 주성분(PC1)과 제2주성분(PC2)의 값을 구하고 $\mathrm{PCA}$ plot를 작성하였다. 또 한, 각 센서별 요구르트 향기성분의 유의성을 검정하고자 SAS 프로그램(Statistical Analysis System, Ver. 9.4, SAS Institute Inc. Cary, NC, USA)을 이용하여 $\mathrm{p}<0.05$ 의 수준에 서 Multivariate Analysis of Variance(MANOVA)를 실시하 였다.

\section{통계분석}

실험 결과의 통계분석은 SAS 9.4(Statistical Analysis System, SAS Institute Inc. Cary, NC, USA)을 이용하여 분산 분석(ANOVA)을 실시하고, Duncan's multiple range test를 이용하여 시료간의 유의적인 차이를 검정하였다 $(\mathrm{p}<0.05)$.

\section{결과 및 고찰}

요구르트의 물리화학적 특성

발효유(8종)와 농후발효유(9종)의 물리화학적 특성을 $\mathrm{pH}$, 총산, 탁도와 점도로 분석하였다(Table 1). 발효유와 농후발효유의 $\mathrm{pH}$ 는 각각 3.46-4.15과 4.17-4.56의 구간으로, 발효유의 $\mathrm{pH}$ 가 농후발효유보다 유의적으로 낮고( $\mathrm{p}<0.05)$, 총산은 발효유가 0.45-0.94 g/100 mL, 농후발효유가 0.75-1.02 g/100 mL으로 유의적인 차이를 보였다 $(\mathrm{p}<0.05)$. $\mathrm{Ko}$ 등(19)은 액상발효유의 $\mathrm{pH}(3.25-4.27)$ 는 드링크 타입인 농후발효유의 $\mathrm{pH}(3.80-4.56)$ 보다 낮다고 보고하였으며, 이 는 본 연구 결과와 유사하였다. Lee 등(21)은 요구르트의 $\mathrm{pH}$ 3.7-4.2가 한국인의 기호에 적합하다고 하였고, Kosikowski(22)는 제조 직후의 신선한 요구르트는 0.9-1.2\% 의 총산을 함유하고, 유통과정 중에 $1.5 \%$ 까지 증가한다고 보고하였다.

농후발효유와 발효유의 탁도는 각각 51.80-214.36와 $19.23-138.99$, 점도는 각각 $25.20-174.20 \mathrm{mPa} \cdot \mathrm{s}$ 와 $14.20-$ 
$22.40 \mathrm{mPa} \cdot \mathrm{s}$ 의 구간으로서, 농후발효유의 탁도와 점도가 발효유보다 유의적으로 높은 경향을 나타내었다 $(\mathrm{p}<0.05)$ (Table 1). 요구르트는 발효 공정 중 lactic acid 등의 산 생성 량이 증가하고 이로 인해 우유의 단백질(casein)이 응고되 어 커드나 입자를 형성하게 되어 탁도 또는 점도가 증가하 므로, 총산함량이 높은 농후발효유의 점도가 발효유보다 높은 것으로 사료된다(1,5). 요구르트의 점도는 소비자들이 품질을 평가하고 제품 구매를 결정하는 중요한 요소로서 (23), 삼백초, 통보릿가루 또는 배양인삼 추출물이 첨가된 요구르트의 점도가 무첨가군의 점도보다 높다는 연구결과 가 보고되고 있다 $(1,2,13)$. 따라서 요구르트는 제조 시 첨가 되는 증점제, 산미 및 향미 증진제, 다양한 과즙 추출물, 또는 발효 원재료로 사용되는 우유의 종류(원유 또는 혼합 탈지분유)는 요구르트 제품의 물리화학적 특성에 영향을 줄 수 있으며, 본 연구에서 분석한 농후발효유는 발효유보 다 신맛이 강하고 탁도와 점도가 높은 것으로 조사되었다.

\section{요구르트의 유기산 조성과 함량}

요구르트에 함유된 주요 유기산은 citric acid와 lactic acid 이고, acetic, malic, formic acids는 소량 또는 미량 함유된 것으로 분석되었다(Table 2). 요구르트 제조를 위한 발효과
정 중 대부분의 유산균은 원유의 lactose로부터 분해된 glucose로부터 lactic acid를 생성하며, 사용되는 유산균주 또는 원유의 종류에 따라 acetic acid, citric acid, formic acid 등의 유기산도 함께 생성된다 $(1,3,13,24)$. 시중 유통되는 요 구르트에 가장 많은 유기산은 lactic acid로서, 발효유 (5.11-9.07 mg/g) 보다 농후발효유(7.31-12.95 mg/g)에 유의 적으로 높게 함유되었는데( $\mathrm{p}<0.05)$, 이는 농후발효유가 발 효유에 비해 발효원재료(원유 or 혼합탈지분유)의 함량이 높아 유산균이 이용할 lactose가 많고, 따라서 lactic acid를 더 많이 생성된 것으로 사료된다. Lactic acid는 요구르트의 보존성 향상 및 유해 미생물 억제 작용을 하며, 우유단백질 의 소화 증진 및 칼슘, 인, 철의 이용률 증진 등의 생리기능 을 가지고 있다(15).

Citric acid는 발효유(0.44-1.57 mg/g)보다 농후발효유 $(1.52-2.61 \mathrm{mg} / \mathrm{g})$ 에 유의적으로 높게 함유되었으며 $(\mathrm{p}<0.05)$, 특히 발효유 중에는 citric acid가 첨가된 FM-6에서 가장 높았고 $(\mathrm{p}<0.05)$, 농후발효유 중에는 과일추출물인 감귤, 레 몬, 자몽, 매실, 탱자 등의 추출물이 함유된 CFM-9, 2, 7, 8에서 높게 조사되었다. Acetic acid는 농후발효유 (0.11-0.31 mg/g)보다 발효유 $(0.16-0.33 \mathrm{mg} / \mathrm{g})$ 에 많이 함유 된 경향을 보였으며, malic acid와 formic acid는 농후발효유

Table 1 . The physicochemical characteristics of commercial yogurt

\begin{tabular}{|c|c|c|c|c|}
\hline Yogurt & $\mathrm{pH}$ & $\begin{array}{c}\text { Total acidity } \\
\text { (lactic acid, } \mathrm{g} / 100 \mathrm{~mL} \text { ) }\end{array}$ & Turbidity ${ }^{1)}$ & $\begin{array}{l}\text { Viscosity } \\
(\mathrm{mPa} \cdot \mathrm{s})\end{array}$ \\
\hline FM-1 ${ }^{2)}$ & $3.58 \pm 0.10^{\mathrm{i3})}$ & $0.65 \pm 0.05^{\mathrm{g}}$ & $30.09 \pm 0.02^{\mathrm{k}}$ & $17.80 \pm 1.98^{\mathrm{ij}}$ \\
\hline FM-2 & $3.79 \pm 0.04^{g}$ & $0.54 \pm 0.00^{\mathrm{h}}$ & $30.92 \pm 0.02^{\mathrm{k}}$ & $21.40 \pm 0.85^{\mathrm{hi}}$ \\
\hline FM-3 & $3.69 \pm 0.01^{\mathrm{h}}$ & $0.66 \pm 0.00^{\mathrm{g}}$ & $18.69 \pm 0.01^{\circ}$ & $16.80 \pm 1.13^{j}$ \\
\hline FM-4 & $4.15 \pm 0.02^{\mathrm{f}}$ & $0.45 \pm 0.03^{\mathrm{i}}$ & $138.99 \pm 0.18^{\mathrm{h}}$ & $22.40 \pm 0.57^{\mathrm{h}}$ \\
\hline FM-5 & $3.59 \pm 0.00^{\mathrm{i}}$ & $0.67 \pm 0.01^{\mathrm{fg}}$ & $19.23 \pm 0.01^{\circ}$ & $14.20 \pm 1.98^{j}$ \\
\hline FM-6 & $3.59 \pm 0.00^{\mathrm{i}}$ & $0.66 \pm 0.04^{\mathrm{g}}$ & $20.66 \pm 0.02^{\mathrm{n}}$ & $15.80 \pm 0.28^{j}$ \\
\hline FM-7 & $3.65 \pm 0.00^{\mathrm{hi}}$ & $0.64 \pm 0.04^{\mathrm{g}}$ & $22.88 \pm 0.00^{\mathrm{m}}$ & $14.40 \pm 0.00^{j}$ \\
\hline FM-8 & $3.46 \pm 0.00^{j}$ & $0.94 \pm 0.06^{\mathrm{ab}}$ & $24.42 \pm 0.00^{1}$ & $16.60 \pm 1.41^{\mathrm{j}}$ \\
\hline Mean \pm SD & $3.69 \pm 0.21$ & $0.65 \pm 0.14$ & $38.23 \pm 40.97$ & $17.43 \pm 3.02$ \\
\hline CFM-1 $1^{2)}$ & $4.35 \pm 0.03^{\text {cd }}$ & $0.77 \pm 0.05^{\text {de }}$ & $167.34 \pm 0.53^{\mathrm{e}}$ & $174.20 \pm 4.81^{\mathrm{a}}$ \\
\hline CFM-2 & $4.41 \pm 0.04^{\mathrm{bc}}$ & $1.02 \pm 0.01^{\mathrm{a}}$ & $198.57 \pm 1.07^{b}$ & $53.20 \pm 0.57^{c}$ \\
\hline CFM-3 & $4.25 \pm 0.00^{\mathrm{e}}$ & $0.85 \pm 0.05^{\mathrm{cd}}$ & $154.79 \pm 0.59^{f}$ & $43.80 \pm 0.28^{\mathrm{e}}$ \\
\hline CFM-4 & $4.28 \pm 0.01^{\mathrm{de}}$ & $0.76 \pm 0.05^{\mathrm{e}}$ & $69.55 \pm 0.78^{\mathrm{i}}$ & $30.40 \pm 0.57^{g}$ \\
\hline CFM-5 & $4.17 \pm 0.00^{f}$ & $0.81 \pm 0.05^{\text {de }}$ & $141.40 \pm 1.07^{g}$ & $71.20 \pm 0.57^{\mathrm{b}}$ \\
\hline CFM-6 & $4.44 \pm 0.06^{b}$ & $0.75 \pm 0.04^{\mathrm{ef}}$ & $51.80 \pm 0.32^{\mathrm{j}}$ & $25.20 \pm 0.57^{\mathrm{h}}$ \\
\hline CFM-7 & $4.32 \pm 0.00^{\mathrm{de}}$ & $0.91 \pm 0.00^{\mathrm{bc}}$ & $185.60 \pm 0.26^{c}$ & $73.80 \pm 4.81^{b}$ \\
\hline CFM-8 & $4.31 \pm 0.05^{\mathrm{de}}$ & $0.80 \pm 0.04^{\text {de }}$ & $180.39 \pm 0.78^{d}$ & $38.00 \pm 0.57^{\mathrm{f}}$ \\
\hline CFM-9 & $4.56 \pm 0.01^{\mathrm{a}}$ & $0.79 \pm 0.02^{\mathrm{de}}$ & $214.36 \pm 0.39^{\mathrm{a}}$ & $48.20 \pm 0.85^{\mathrm{d}}$ \\
\hline Mean \pm SD & $4.34 \pm 0.12$ & $0.83 \pm 0.09$ & $151.53 \pm 56.11$ & $62.00 \pm 45.19$ \\
\hline
\end{tabular}

${ }^{1)}$ Turbidity was expressed by OD at $600 \mathrm{~nm} \times$ dilution factor

${ }^{2)} \mathrm{FM}$, fermented milk, CFM, condensed fermented milk.

${ }^{3) a-0}$ Means with the different superscripts in the same column are significantly different by Duncan's multiple range test at $\mathrm{p}<0.05$. 
Table 2. The content of organic acid in commercial yogurt

\begin{tabular}{|c|c|c|c|c|c|}
\hline \multirow{2}{*}{ Yogurt } & \multicolumn{5}{|c|}{ Organic acids (mg/g) } \\
\hline & Citric acid & Lactic acid & Acetic acid & Malic acid & Formic acid \\
\hline $\mathrm{FM}-1^{1)}$ & $0.74 \pm 0.01^{\mathrm{i} 2)}$ & $6.98 \pm 0.02^{\mathrm{h}}$ & $0.22 \pm 0.02^{\mathrm{cd}}$ & $\mathrm{ND}^{3)}$ & $\mathrm{ND}$ \\
\hline FM-2 & $0.71 \pm 0.12^{\mathrm{ij}}$ & $5.20 \pm 0.05^{\mathrm{k}}$ & $0.20 \pm 0.00^{\mathrm{de}}$ & $\mathrm{ND}$ & ND \\
\hline FM-3 & $0.66 \pm 0.03^{\mathrm{ij}}$ & $6.56 \pm 0.39^{i}$ & $0.24 \pm 0.02^{\mathrm{bc}}$ & $\mathrm{ND}$ & $\mathrm{ND}$ \\
\hline FM-4 & $0.97 \pm 0.06^{\mathrm{h}}$ & $5.81 \pm 0.07^{\mathrm{j}}$ & $0.16 \pm 0.03^{\mathrm{fg}}$ & $\mathrm{ND}$ & ND \\
\hline FM-5 & $0.62 \pm 0.00^{j}$ & $6.45 \pm 0.05^{\mathrm{i}}$ & $0.33 \pm 0.02^{\mathrm{a}}$ & $\mathrm{ND}$ & $\mathrm{ND}$ \\
\hline FM-6 & $1.57 \pm 0.02^{\mathrm{fg}}$ & $5.11 \pm 0.07^{\mathrm{k}}$ & $0.25 \pm 0.01^{\mathrm{b}}$ & $\mathrm{ND}$ & $\mathrm{ND}$ \\
\hline FM-7 & $0.61 \pm 0.02^{\mathrm{j}}$ & $6.36 \pm 0.06^{\mathrm{i}}$ & $0.24 \pm 0.01^{\mathrm{bc}}$ & $\mathrm{ND}$ & ND \\
\hline FM-8 & $0.44 \pm 0.04^{\mathrm{k}}$ & $9.07 \pm 0.16^{\mathrm{e}}$ & $0.32 \pm 0.01^{\mathrm{a}}$ & $\mathrm{ND}$ & $\mathrm{ND}$ \\
\hline Mean \pm SD & $0.79 \pm 0.35$ & $6.44 \pm 1.25$ & $0.24 \pm 0.06$ & $\mathrm{ND}$ & ND \\
\hline CFM- $1^{1)}$ & $1.56 \pm 0.05^{\mathrm{fg}}$ & $8.01 \pm 0.05^{\mathrm{f}}$ & $0.11 \pm 0.01^{\mathrm{h}}$ & $0.33 \pm 0.07^{\mathrm{a}}$ & $\mathrm{ND}$ \\
\hline CFM-2 & $2.54 \pm 0.01^{\mathrm{ab}}$ & $12.95 \pm 0.05^{\mathrm{a}}$ & $0.31 \pm 0.00^{\mathrm{a}}$ & $\mathrm{ND}$ & $0.06 \pm 0.00^{\mathrm{a}}$ \\
\hline CFM-3 & $1.72 \pm 0.01^{\mathrm{e}}$ & $9.04 \pm 0.10^{\mathrm{e}}$ & $0.18 \pm 0.00^{\text {ef }}$ & $\mathrm{ND}$ & $0.06 \pm 0.00^{\mathrm{a}}$ \\
\hline CFM-4 & $1.63 \pm 0.06^{\mathrm{ef}}$ & $9.69 \pm 0.01^{\mathrm{d}}$ & $\mathrm{ND}$ & $\mathrm{ND}$ & $0.06 \pm 0.01^{\mathrm{a}}$ \\
\hline CFM-5 & $1.52 \pm 0.00^{\mathrm{g}}$ & $9.95 \pm 0.08^{c}$ & $\mathrm{ND}$ & ND & ND \\
\hline CFM-6 & $1.82 \pm 0.00^{\mathrm{d}}$ & $7.31 \pm 0.05^{\mathrm{g}}$ & $0.23 \pm 0.01^{\mathrm{bc}}$ & $\mathrm{ND}$ & $\mathrm{ND}$ \\
\hline CFM-7 & $2.47 \pm 0.05^{\mathrm{b}}$ & $8.99 \pm 0.05^{\mathrm{e}}$ & $0.18 \pm 0.01^{\mathrm{ef}}$ & $0.13 \pm 0.05^{b}$ & $0.06 \pm 0.00^{\mathrm{a}}$ \\
\hline CFM-8 & $2.10 \pm 0.04^{\mathfrak{c}}$ & $8.06 \pm 0.08^{\mathrm{f}}$ & $0.15 \pm 0.01^{g}$ & $0.21 \pm 0.00^{\mathrm{ab}}$ & ND \\
\hline CFM-9 & $2.61 \pm 0.01^{\mathrm{a}}$ & $11.01 \pm 0.16^{b}$ & $0.26 \pm 0.01^{\mathrm{b}}$ & $\mathrm{ND}$ & ND \\
\hline Mean \pm SD & $2.00 \pm 0.44$ & $9.44 \pm 1.73$ & $0.20 \pm 0.07$ & $0.22 \pm 0.10$ & $0.06 \pm 0.00$ \\
\hline
\end{tabular}

${ }^{1)} \mathrm{FM}$, fermented milk; CFM, condensed fermented milk.

${ }^{2) a-k}$ Means with the different superscripts in the same column are significantly different by Duncan's multiple range test at $p<0.05$.

${ }^{3} \mathrm{ND}$, not detected.

군에서만 검출되었고 그 중 3-4개의 제품에서만 각각 $0.13-0.33 \mathrm{mg} / \mathrm{g}$ 와 $0.06 \mathrm{mg} / \mathrm{g}$ 의 함량으로 검출되었다(Table 2). 요구르트에 관한 선행연구 결과를 살펴보면 lactic acid 가 주요 유기산이고, 이외에 Lactobacillus bulgaricus와 Streptococcus thermophilus로 제조된 요구르트에서 acetic, citric, propionic, formic acid, oxalic, tartaric acid가 검출되었 고 $(1,13,14)$, 삼백초, 배양인삼, 오디분말 등을 첨가하여 제 조할 경우 특정 유기산의 함량이 증가 또는 감소하였다는 연구결과가 보고되고 있다 $(1,13,14)$.

따라서 요구르트는 사용된 유산균주과 원유의 종류 및 제조 시 첨가된 과즙 첨가물들에 의해 유기산의 종류와 그 함량이 달라질 수 있으며, 본 연구에서는 발효유보다 농후발효유에 함유된 유기산의 종류가 많고 그 함유량도 높았으며, 특히 lactic acid함량은 citric acid의 8.15-4.72배, acetic acid의 26.83-47.20배 높게 나타났다.

\section{요구르트의 당 조성과 함량}

시중 판매되는 요구르트의 주요 당을 HPLC로 분석한 결과 발효유의 당은 sucrose $>$ fructose $>$ glucose $>$ lactose $>$ maltose의 순으로, 농후발효유의 당은 fructose > lactose
$>$ sucrose $>$ glucose $>$ maltose의 순으로 함유되었으며, 발효 유의 총당함량 $(115.18 \mathrm{mg} / \mathrm{g})$ 이 농후발효유 $(57.72 \mathrm{mg} / \mathrm{g})$ 보 다 유의적으로 높았다( $\mathrm{p}<0.05)($ Table 3). 요구르트의 원재료 인 원유와 탈지분유의 lactose는 발효과정 동안 유산균에 의해 glucose와 galactose로 분해되므로, 발효시간이 길어질 수록 lactose의 함량은 감소하는 반면 glucose는 증가하지만 동시에 glucose는 유산균에 의해 발효되어 lactic acid, acetic acid, ethanol, $\mathrm{CO}_{2}$ 등의 대사산물을 생성하므로 그 함량이 감소하게 된다(3,25).

요구르트에서 검출된 5 가지 당 중에서 sucrose 함량의 범위가 가장 넓게 나타났으며, 발효유에서는 ND-129.37 $\mathrm{mg} / \mathrm{g}$, 농후발효유에서는 ND-43.74 mg/g으로 분석되어, 발 효유에 첨가된 sucrose 함량의 범위가 더 넓고, 그 함유량은 유의적으로 높은 것으로 조사되었다( $<<0.05)$. Fructose 함량 은 ND-61.73 mg/g(발효유) 또는 ND-45.54 mg/g(농후발효 유), glucose 함량은 4.02-30.69 mg/g(발효유) 또는 ND-26.14 $\mathrm{mg} / \mathrm{g}$ (농후발효유)으로 그 함유량의 범위가 넓게 나타났다. 본 연구에서 분석된 요구르트에는 발효와 단맛 증진을 위해 당류(정백당, 액상과당, 결정과당, 포도당, 올리고당; 제품 label 참조)가 첨가되었고, 첨가량이 광범위하여 분석된 당 
Table 3. The content of sugar in commercial yogurt

\begin{tabular}{|c|c|c|c|c|c|c|}
\hline \multirow{2}{*}{ Yogurt } & \multicolumn{6}{|c|}{ Sugars (mg/g) } \\
\hline & Fructose & Glucose & Sucrose & Lactose & Maltose & Total sugars \\
\hline FM-1 ${ }^{1)}$ & $61.73 \pm 0.03^{22)}$ & $30.69 \pm 0.58^{\mathrm{a}}$ & $27.74 \pm 0.58^{\mathrm{f}}$ & $30.53 \pm 0.39^{d}$ & $5.20 \pm 0.73^{b}$ & $155.89 \pm 1.16^{b}$ \\
\hline FM-2 & $14.43 \pm 0.07^{j}$ & $10.99 \pm 0.17^{\mathrm{h}}$ & $92.79 \pm 0.33^{b}$ & $25.41 \pm 0.82^{\mathrm{f}}$ & $1.76 \pm 0.11^{\mathrm{g}}$ & $145.39 \pm 1.50^{c}$ \\
\hline FM-3 & $0.88 \pm 0.14^{1}$ & $4.02 \pm 0.11^{\mathrm{k}}$ & $129.37 \pm 0.32^{\mathrm{a}}$ & $24.98 \pm 2.73^{f}$ & $\mathrm{ND}^{3)}$ & $159.25 \pm 3.0^{\mathrm{a}}$ \\
\hline FM-4 & $33.92 \pm 0.23^{\mathrm{e}}$ & $24.35 \pm 0.24^{\mathrm{e}}$ & $1.21 \pm 0.14^{\mathrm{h}}$ & $20.56 \pm 0.33^{g}$ & $2.49 \pm 0.25^{\mathrm{efg}}$ & $82.53 \pm 0.91^{\mathrm{e}}$ \\
\hline FM-5 & $30.59 \pm 0.67^{\mathrm{f}}$ & $24.73 \pm 0.53^{\mathrm{de}}$ & $\mathrm{ND}$ & $12.62 \pm 0.49^{\mathrm{i}}$ & $7.25 \pm 0.11^{\mathrm{a}}$ & $75.18 \pm 0.52^{\mathrm{f}}$ \\
\hline FM-6 & $35.11 \pm 0.02^{\mathrm{d}}$ & $29.88 \pm 0.86^{\mathrm{a}}$ & $\mathrm{ND}$ & $24.25 \pm 0.70^{f}$ & $4.58 \pm 0.48^{\mathrm{bc}}$ & $93.81 \pm 2.06^{d}$ \\
\hline FM-7 & $23.21 \pm 0.09^{\mathrm{g}}$ & $17.86 \pm 0.11^{\mathrm{f}}$ & ND & $16.62 \pm 0.21^{\mathrm{h}}$ & $4.70 \pm 0.07^{\mathrm{bc}}$ & $52.39 \pm 0.08^{g}$ \\
\hline FM-8 & $37.75 \pm 0.19^{c}$ & $27.47 \pm 0.27^{\mathrm{b}}$ & $73.24 \pm 0.88^{c}$ & $8.55 \pm 0.43^{j}$ & $\mathrm{ND}$ & $147.02 \pm 0.86^{c}$ \\
\hline Mean \pm SD & $29.70 \pm 17.90$ & $21.25 \pm 9.54$ & $64.87 \pm 51.09$ & $20.44 \pm 7.36$ & $4.33 \pm 1.97$ & $115.18 \pm 40.42$ \\
\hline CFM-1 ${ }^{1)}$ & $14.14 \pm 0.46^{j}$ & $26.14 \pm 0.75^{c}$ & $3.69 \pm 0.54^{g}$ & $0.19 \pm 0.05^{\mathrm{k}}$ & $3.69 \pm 0.09^{\mathrm{cd}}$ & $47.86 \pm 0.63^{j}$ \\
\hline CFM-2 & $\mathrm{ND}$ & $\mathrm{ND}$ & $38.42 \pm 0.07^{\mathrm{e}}$ & $51.68 \pm 1.52^{\mathrm{a}}$ & $2.05 \pm 0.62^{\mathrm{fg}}$ & $92.15 \pm 2.21^{\mathrm{d}}$ \\
\hline CFM-3 & ND & $\mathrm{ND}$ & $43.74 \pm 0.62^{\mathrm{d}}$ & $34.19 \pm 0.26^{\mathrm{c}}$ & ND & $77.93 \pm 0.36^{\mathrm{f}}$ \\
\hline CFM-4 & $\mathrm{ND}$ & ND & $\mathrm{ND}$ & $37.32 \pm 0.43^{b}$ & $2.11 \pm 0.22^{\mathrm{fg}}$ & $39.42 \pm 0.65^{1}$ \\
\hline CFM-5 & $13.04 \pm 0.46^{\mathrm{k}}$ & $6.80 \pm 0.21^{\mathrm{i}}$ & ND & $34.66 \pm 0.50^{c}$ & $3.00 \pm 1.32^{\mathrm{def}}$ & $57.50 \pm 1.57^{\mathrm{h}}$ \\
\hline CFM-6 & $\mathrm{ND}$ & $13.33 \pm 0.29^{\mathrm{g}}$ & ND & $8.52 \pm 0.13^{j}$ & $\mathrm{ND}$ & $21.85 \pm 0.42^{\mathrm{m}}$ \\
\hline CFM-7 & $20.97 \pm 0.12^{\mathrm{h}}$ & $18.25 \pm 0.09^{f}$ & ND & $2.61 \pm 0.68^{k}$ & $3.63 \pm 0.17^{\mathrm{cde}}$ & $45.47 \pm 1.06^{\mathrm{k}}$ \\
\hline CFM-8 & $45.54 \pm 0.45^{\mathrm{b}}$ & $5.45 \pm 0.18^{j}$ & $1.59 \pm 0.19^{\mathrm{h}}$ & $28.18 \pm 0.43^{\mathrm{e}}$ & $3.58 \pm 0.08^{\mathrm{cde}}$ & $84.34 \pm 0.96^{\mathrm{e}}$ \\
\hline CFM-9 & $18.14 \pm 0.37^{\mathrm{i}}$ & $25.67 \pm 0.94^{\mathrm{cd}}$ & $3.65 \pm 0.26^{g}$ & $2.36 \pm 0.71^{\mathrm{k}}$ & $3.11 \pm 0.32^{\text {def }}$ & $52.93 \pm 0.67^{\mathrm{i}}$ \\
\hline Mean \pm SD & $22.37 \pm 13.34$ & $15.94 \pm 8.99$ & $18.22 \pm 20.97$ & $22.19 \pm 18.98$ & $3.02 \pm 0.70$ & $57.72 \pm 22.90$ \\
\hline
\end{tabular}

${ }^{1)} \mathrm{FM}$, fermented milk; CFM, condensed fermented milk.

2)a-m Means with the different superscripts in the same column are significantly different by Duncan's multiple range test at $\mathrm{p}<0.05$.

${ }^{3)} \mathrm{ND}$, not detected.

의 종류와 그 함량이 다양한 것으로 사료된다. 본 연구결과 와 유사하게 시중에서 판매되는 요구르트를 수거하여 분석 한 선행연구결과를 살펴보면 첨가물이 없는 plain 요구르트 는 다량의 lactose 및 소량의 glucose와 galactose를 함유하지 만, flavor(strawberry, lemon, plantain, pineapple)가 첨가된 요구르트(26) 또는 puree fruits, syrup과 sugar가 첨가된 요구 르트에서는 fructose, sucrose가 추가로 검출되고 sucrose 함 량이 lactose 보다 높은 것으로 조사되었다(6). 따라서 시중 에 유통되는 발효유와 농후발효유는 발효원재료의 함량 및 제조시 첨가되는 다양한 첨가물들로 인해 당 조성과 그 함량의 차이가 있으며, 발효유가 농후발효유보다 총당 함량이 2 배 높고 그 중 sucrose의 함량이 3.6배 높아 단맛이 강하였다.

\section{요구르트의 조지방 및 CLA 함량}

CLA는 반추동물의 유제품인 우유(5.4-7.0 mg/g fat), 요구 르트(1.7-4.8 mg/g fat), 치즈(2.9-7.1 mg/g fat), 버터 $(4.7 \mathrm{mg} / \mathrm{g}$ fat)와 육류인 소고기(2.9-4.3 mg/g fat)와 양고기 $(5.6 \mathrm{mg} / \mathrm{g}$ fat)에서 주로 발견되며, 그중 cis-9, trans-11 CLA는 총 CLA 이성질체들의 $80-95 \%$ 를 차지한다(12). 시판 요구르트의 조
지방과 cis-9, trans-11 CLA의 함량은 발효유에서 각각 $0.02-1.44 \mathrm{~g} / 100 \mathrm{~g}$ 와 $0.00-2.17 \mathrm{mg} / 100 \mathrm{~g}$, 농후발효유에서 각각 0.93-3.16 g/100 g과 2.99-10.97 mg/100 g으로, 농후발 효유가 발효유보다 10.81배 많은 조지방과 23.65배 높은 CLA를 함유하였고, CLA 함량은 농후발효유에서 유의적으 로 높게 나타났다(p<0.05)(Table 4). 이는 요구르트 제조 시 사용된 원재료인 우유의 종류(원유 또는 탈지분유) 차이 에서 기인된 것으로 생각된다. 분석 시료인 요구르트 용기 에 표기된 label를 살펴보면 대부분의 발효유(FM 1-8, 4제 외)는 탈지분유로부터 제조되어 조지방 함량이 $<0.03 \mathrm{~g} / 100$ $\mathrm{g}$, CLA 함량이 $<0.15 \mathrm{mg} / 100 \mathrm{~g}$ 으로 미량 존재하였고, FM-4 와 모든 농후발효유(CFM 1-9)는 원유 또는 원유와 탈지분 유의 혼합물로부터 제조되므로 조지방과 CLA 함량이 높은 것으로 사료된다. 따라서 요구르트의 CLA 함량 차이는 발 효유 제조시 사용된 원재료의 차이에서 기인되며, 요구르 트의 지방함량이 높을수록 CLA 함량도 증가하였음을 알 수 있었다. 시판 요구르트제품의 CLA 농도를 조사한 Lee 등(27)의 연구결과에 따르면 cis-9, trans-11 CLA 함량은 $0.2-14.8 \mathrm{mg} / 100 \mathrm{~g}$ 으로서 본 연구결과와 유사하였고, 원유 사용 비율이 높을수록 CLA 함량이 높다고 보고하였다. 
Table 4. The content of lipid and cis-9, trans-11 conjugated linoleic acid (CLA) in commercial yogurt

\begin{tabular}{|c|c|c|c|c|c|}
\hline Yogurt & Total Lipid $(\mathrm{g} / 100 \mathrm{~g})$ & CLA (mg/100 g) & Yogurt & Total Lipid (g/100 g) & CLA (mg/100 g) \\
\hline FM-1 $1^{1)}$ & $0.02 \pm 0.00$ & $0.07 \pm 0.00^{92)}$ & CFM-1 ${ }^{1)}$ & $2.17 \pm 0.01$ & $6.92 \pm 0.57^{d}$ \\
\hline FM-2 & $0.02 \pm 0.00$ & $0.15 \pm 0.00^{g}$ & CFM-2 & $0.93 \pm 0.06$ & $2.99 \pm 0.30^{f}$ \\
\hline FM-3 & $0.02 \pm 0.00$ & $0.07 \pm 0.00^{\mathrm{g}}$ & CFM-3 & $1.71 \pm 0.09$ & $5.17 \pm 0.33^{\mathrm{e}}$ \\
\hline FM-4 & $1.44 \pm 0.07$ & $2.17 \pm 0.06^{\mathrm{f}}$ & CFM-4 & $3.16 \pm 0.14$ & $10.03 \pm 0.75^{b}$ \\
\hline FM-5 & $0.02 \pm 0.00$ & $0.00 \pm 0.00^{\circ}$ & CFM-5 & $2.97 \pm 0.12$ & $9.33 \pm 0.62^{b}$ \\
\hline FM-6 & $0.10 \pm 0.11$ & $0.01 \pm 0.00^{g}$ & CFM-6 & $2.15 \pm 0.00$ & $8.17 \pm 0.45^{\mathrm{c}}$ \\
\hline FM-7 & $0.02 \pm 0.00$ & $0.01 \pm 0.00^{g}$ & CFM-7 & $2.94 \pm 0.23$ & $10.97 \pm 0.86^{\mathrm{a}}$ \\
\hline \multirow[b]{2}{*}{ FM-8 } & \multirow[b]{2}{*}{$0.03 \pm 0.01$} & \multirow[b]{2}{*}{$0.00 \pm 0.00^{\mathrm{g}}$} & CFM-8 & $1.78 \pm 0.06$ & $5.25 \pm 0.07^{\mathrm{e}}$ \\
\hline & & & CFM-9 & $2.60 \pm 0.02$ & $7.17 \pm 0.68^{\mathrm{d}}$ \\
\hline Mean \pm SD & $0.21 \pm 0.50$ & $0.31 \pm 0.75$ & Mean \pm SD & $2.27 \pm 0.73$ & $7.33 \pm 2.58$ \\
\hline
\end{tabular}

${ }^{1)} \mathrm{FM}$, fermented milk; CFM, condensed fermented milk.

${ }^{2) a-g}$ Means with the different superscripts in the same column are significantly different by Duncan's multiple range test at $p<0.05$.

전자코를 이용한 요구르트의 향기패턴 분석

전자코는 인간의 코를 디지털화한 시스템으로 장착된 센서들을 이용하여 식품의 향기 성분의 패턴을 분석할 수 있어 우유의 신선도 예측(28), 우유의 저장성 평가분석(29), 시유의 관능적 품질 특성 분석(30) 등의 연구들에 이용되고 있다. 요구르트 향기성분에 대한 전자코의 센서별 감응도 결과 값으로 $\mathrm{PCA}$ 를 실시하여 제 1 주성분 $(\mathrm{PC} 1)$ 과 제 2 주성 분(PC2)의 고유 값(eigen value)인 0.736과 0.109와 누적 기 여율(cumulative proportion) $84.48 \%$ 를 얻은 후, $\mathrm{PC} 1$ 과 $\mathrm{PC} 2$ 로 구성된 $\mathrm{PCA}$ plot을 작성하여 총 5 개의 group으로 clustering된 향기패턴을 확인하였다(Fig. 1). 전자코 분석 시료 중 CFM-8와 FM-1은 각각 독립된 group I과 II 으로 구별되어 차별화된 향기성분패턴을 나타내었다. 이외의 발 효유들은 group III(CFM-1과 FM-2, 3, 6, 7, PC1: 0.40-0.90의 구간), group IV(FM-4, 8, PC1: -0.30-0.33), group V(CFM-2, $3,4,5,6,7,9$ 와 $\mathrm{FM}-5, \mathrm{PC} 1 ;-1.26-0.49)$ 의 각기 다른 3 개의 향기 그룹을 형성하고 있다. Table 5의 각 센서별 감응도를 살펴보면 감응도가 높은 발효유일수록 $\mathrm{PC1}$ 값이 증가하여 PCA plot의 오른쪽에 위치하는 경향을 나타내었다. 또한, 각 센서별 감응도의 유의차를 MANOVA로 검정한 결과,

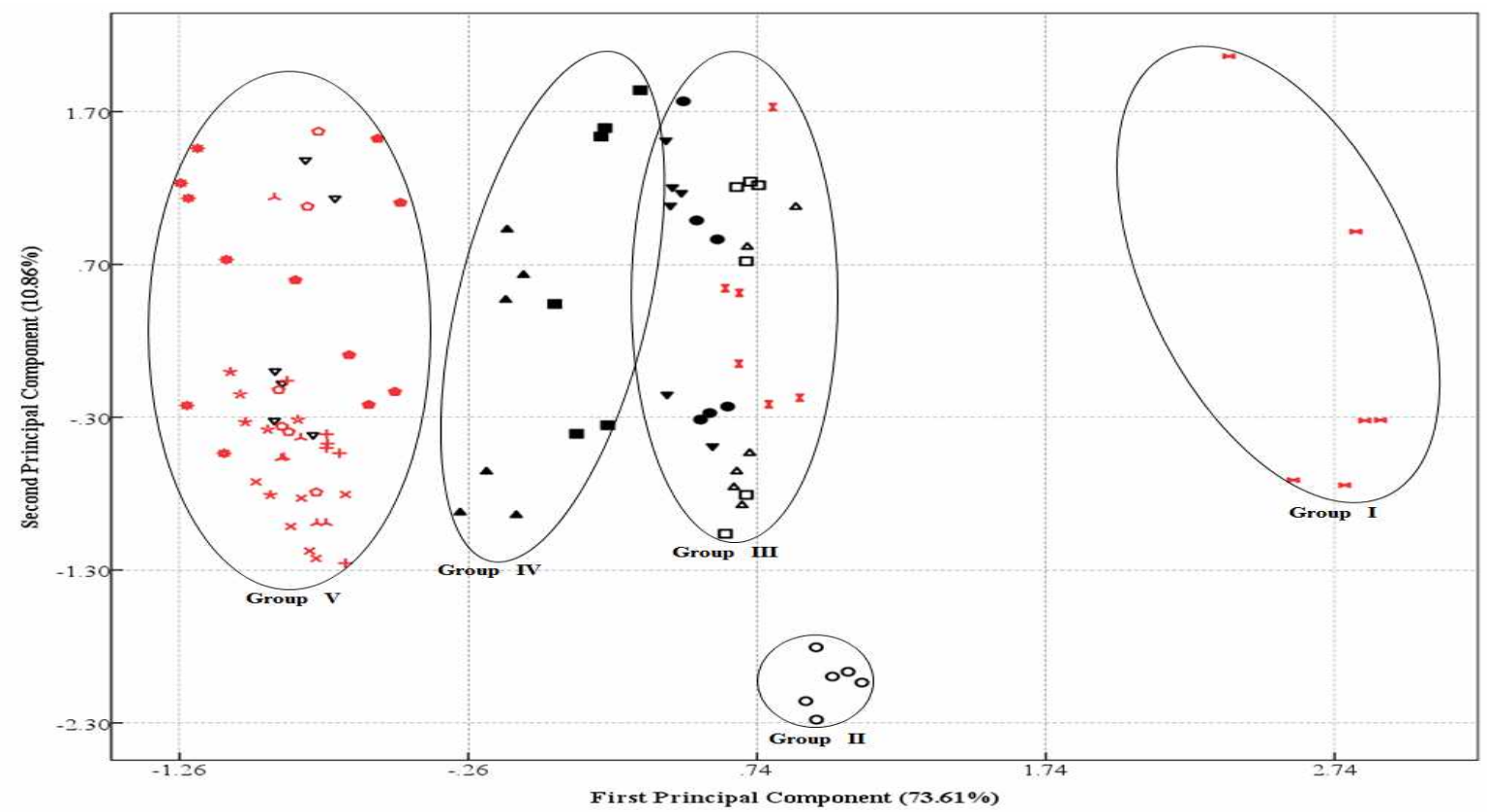

Fig. 1. The principal component analysis plot of commercial yogurt analyzed with electronic nose. 
Table 5 . The sensor response $\left(\Delta R / R_{0}\right)$ of commercial yogurt analyzed by electronic nose

\begin{tabular}{|c|c|c|c|c|c|c|c|c|c|c|}
\hline Yogurt & $\mathrm{SY} / \mathrm{G}$ & AAA & $\mathrm{SY} / \mathrm{Gh}$ & $\mathrm{Y} / \mathrm{gCTl}$ & $\mathrm{T} 30 / 1$ & $\mathrm{P} 10 / 1$ & $\mathrm{P} 10 / 2$ & $\mathrm{P} 40 / 1$ & $\mathrm{~T} 70 / 2$ & PA2 \\
\hline FM-1 ${ }^{1)}$ & $-0.02 \pm 0.00^{\mathrm{i} 2)}$ & $00 \pm 0.00^{\mathrm{a}}$ & $-0.02 \pm 0.00^{\mathrm{h}}$ & $0.00 \pm 0.00^{c}$ & $0.31 \pm 0.01^{\mathfrak{c}}$ & $0.05 \pm 0.00^{f}$ & $0.07 \pm 0.00^{\mathrm{e}}$ & $0.05 \pm 0.00^{e}$ & $0.34 \pm 0.01^{\mathrm{c}}$ & $0.34 \pm 0.01^{\mathrm{f}}$ \\
\hline FM-2 & $-0.01 \pm 0.00^{\mathrm{gh}}$ & $0.00 \pm 0.00^{\mathrm{a}}$ & $-0.01 \pm 0.00^{\mathrm{de}}$ & $0.00 \pm 0.00^{\mathrm{abc}}$ & $0.29 \pm 0.01^{\mathrm{d}}$ & $0.06 \pm 0.00^{\mathrm{d}}$ & $0.08 \pm 0.00^{c}$ & $0.06 \pm 0.00^{\mathrm{d}}$ & $0.33 \pm 0.01^{\mathrm{d}}$ & $0.40 \pm 0.01^{\mathrm{c}}$ \\
\hline FM-3 & $-0.01 \pm 0.00^{\mathrm{h}}$ & $0.00 \pm 0.00^{\mathrm{a}}$ & $-0.01 \pm 0.00^{f}$ & $0 \pm 0.00^{\mathrm{abc}}$ & $0.31 \pm 0.01^{\mathrm{c}}$ & $06 \pm 0.00^{\mathrm{d}}$ & $0.08 \pm 0.00^{\mathrm{cd}}$ & $0.06 \pm 0.00^{\mathrm{cd}}$ & $0.35 \pm 0.01^{\mathrm{c}}$ & $0.41 \pm 0.01^{\mathrm{c}}$ \\
\hline FM-4 & $0.00 \pm 0.00^{\text {cde }}$ & $0.00 \pm 0.00^{\mathrm{a}}$ & $0.00 \pm 0.00^{c}$ & $0.00 \pm 0.00^{\mathrm{abc}}$ & $.27 \pm 0.01^{\mathrm{e}}$ & $0.05 \pm 0.00^{\mathrm{e}}$ & $.07 \pm 0.00^{f}$ & $0.05 \pm 0.00^{\mathrm{e}}$ & $0.31 \pm 0.01^{\mathrm{e}}$ & $0.35 \pm 0.01^{\mathrm{f}}$ \\
\hline FM-5 & $0.00 \pm 0.00^{\mathrm{a}}$ & $0.00 \pm 0.00^{\mathrm{a}}$ & $0.00 \pm 0.00^{\mathrm{b}}$ & $0.00 \pm 0.00^{\mathrm{abc}}$ & $0.10 \pm 0.00^{\mathrm{h}}$ & $0.03 \pm 0.00^{\mathrm{h}}$ & $0.03 \pm 0.00^{\mathrm{i}}$ & $0.03 \pm 0.00^{\mathrm{h}}$ & $.11 \pm 0.00^{\mathrm{h}}$ & $0.15 \pm 0.00^{\mathrm{i}}$ \\
\hline FM-6 & $-0.01 \pm 0.00^{\text {defg }}$ & $0.00 \pm 0.00^{\mathrm{a}}$ & $-0.01 \pm 0.00^{d}$ & $0.00 \pm 0.00^{\mathrm{abc}}$ & $0.27 \pm 0.01^{\mathrm{e}}$ & $0.07 \pm 0.00^{c}$ & $0.08 \pm 0.00^{\mathrm{cd}}$ & $0.06 \pm 0.00^{\text {cd }}$ & $.31 \pm 0.01^{e}$ & $0.37 \pm 0.01^{e}$ \\
\hline FM-7 & $-0.01 \pm 0.00^{\mathrm{h}}$ & $0.00 \pm 0.00^{\mathrm{a}}$ & $-0.01 \pm 0.00^{f}$ & $0.00 \pm 0.00^{\mathrm{bc}}$ & $0.30 \pm 0.00^{c}$ & $0.07 \pm 0.00^{c}$ & $0.08 \pm 0.00^{c}$ & $0.06 \pm 0.00^{\text {cd }}$ & $0.34 \pm 0.00^{c}$ & $0.39 \pm 0.01^{\mathrm{d}}$ \\
\hline FM-8 & $-0.01 \pm 0.00^{\mathrm{fgh}}$ & $0^{\mathrm{a}}$ & $-0.01 \pm 0.00^{\mathrm{e}}$ & $0.00 \pm 0.00^{\mathrm{abc}}$ & $0.18 \pm 0.00^{f}$ & $0.04 \pm 0.00^{g}$ & $0.05 \pm 0.00^{\mathrm{g}}$ & $0.04 \pm 0.00^{f}$ & $0.20 \pm 0.00^{f}$ & $0.23 \pm 0.00^{g}$ \\
\hline CFM-1 & $-0.01 \pm 0.00^{\mathrm{efg}}$ & 0.00 & $-0.01 \pm 0.00^{d}$ & $0.00 \pm 0.00^{\mathrm{abc}}$ & $0.36 \pm 0.01^{b}$ & $0.07 \pm 0.00^{\mathrm{b}}$ & $0.09 \pm 0.00^{\mathrm{b}}$ & $0.07 \pm 0.00^{b}$ & $0.42 \pm 0.01^{b}$ & $0.44 \pm 0.01^{\mathrm{b}}$ \\
\hline CFM-2 & $0.00 \pm 0.00^{\mathrm{bcd}}$ & $0.00 \pm 0.00^{\mathrm{a}}$ & $0.00 \pm 0.00^{\mathrm{b}}$ & $0.00 \pm 0.00^{\mathrm{abc}}$ & $0.09 \pm 0.00^{\mathrm{i}}$ & $0.03 \pm 0.00^{\mathrm{h}}$ & $0.03 \pm 0.00^{\mathrm{i}}$ & $0.03 \pm 0.00^{\mathrm{h}}$ & $0.10 \pm 0.00^{\mathrm{h}}$ & $0.17 \pm 0.01^{\mathrm{h}}$ \\
\hline CFM-3 & $-0.01 \pm 0.00^{\mathrm{def}}$ & $0.00 \pm 0.00^{\mathrm{a}}$ & $0.00 \pm 0.00^{\mathrm{c}}$ & $0.00 \pm 0.00^{\mathrm{abc}}$ & $0.07 \pm 0.00^{\mathrm{k}}$ & $0.02 \pm 0.00^{i}$ & $0.03 \pm 0.00^{\mathrm{j}}$ & $0.02 \pm 0.00^{j}$ & $0.08 \pm 0.01^{j}$ & $0.13 \pm 0.01^{\mathrm{j}}$ \\
\hline CFM-4 & $0.00 \pm 0.00^{\mathrm{a}}$ & $0.00 \pm 0.00^{\mathrm{a}}$ & $0.00 \pm 0.00^{b}$ & $0.00 \pm 0.00^{\mathrm{abc}}$ & $0.07 \pm 0.00^{\mathrm{jk}}$ & $0.02 \pm 0.00^{\mathrm{ij}}$ & $0.03 \pm 0.00^{j}$ & $0.02 \pm 0.00^{\mathrm{ij}}$ & $0.08 \pm 0.00^{\mathrm{ij}}$ & $0.14 \pm 0.00^{\mathrm{i}}$ \\
\hline CFM-5 & $0.00 \pm 0.00^{\mathrm{cde}}$ & $0.00 \pm 0.00^{\mathrm{a}}$ & $0.00 \pm 0.00^{b}$ & $0.00 \pm 0.00^{\mathrm{abc}}$ & $0.08 \pm 0.00^{\mathrm{ij}}$ & $0.03 \pm 0.00^{\mathrm{hi}}$ & $0.03 \pm 0.00^{\mathrm{ij}}$ & $0.02 \pm 0.00^{\mathrm{hi}}$ & $0.09 \pm 0.00^{\mathrm{i}}$ & $0.15 \pm 0.01^{\mathrm{i}}$ \\
\hline CFM-6 & $0.00 \pm 0.00^{\mathrm{ab}}$ & $0.00 \pm 0.00^{\mathrm{a}}$ & $0.00 \pm 0.00^{\mathrm{a}}$ & $0.00 \pm 0.00^{\mathrm{ab}}$ & $0.05 \pm 0.00^{1}$ & $0.02 \pm 0.00^{\mathrm{k}}$ & $0.02 \pm 0.00^{\mathrm{k}}$ & $0.02 \pm 0.00^{\mathrm{k}}$ & $0.05 \pm 0.00^{k}$ & $0.09 \pm 0.00^{\mathrm{k}}$ \\
\hline CFM-7 & $0.00 \pm 0.00^{\mathrm{abc}}$ & $0.00 \pm 0.00^{\mathrm{a}}$ & $0.00 \pm 0.00^{\mathrm{b}}$ & $0.00 \pm 0.00^{\mathrm{ab}}$ & $0.09 \pm 0.00^{\mathrm{i}}$ & $0.03 \pm 0.00^{\mathrm{h}}$ & $0.03 \pm 0.00^{\mathrm{i}}$ & $0.03 \pm 0.0 \mathrm{~h}^{\mathrm{hi}}$ & $0.10 \pm 0.00^{\mathrm{h}}$ & $0.16 \pm 0.00^{\mathrm{h}}$ \\
\hline CFM-8 & $-0.02 \pm 0.00^{\mathrm{i}}$ & $0.00 \pm 0.00^{\mathrm{a}}$ & $-0.01 \pm 0.00^{g}$ & $0.00 \pm 0.00^{\mathrm{bc}}$ & $0.55 \pm 0.02^{\mathrm{a}}$ & $0.14 \pm 0.00^{\mathrm{a}}$ & $0.15 \pm 0.00^{\mathrm{a}}$ & $0.12 \pm 0.00^{\mathrm{a}}$ & $0.61 \pm 0.00^{\mathrm{a}}$ & $0.65 \pm 0.01^{\mathrm{a}}$ \\
\hline CFM-9 & $0.00 \pm 0.00^{\mathrm{a}}$ & $0.00 \pm 0.00^{\mathrm{a}}$ & $0.00 \pm 0.00^{b}$ & $0.00 \pm 0.00^{\mathrm{a}}$ & $0.13 \pm 0.01^{g}$ & $0.04 \pm 0.00^{\mathrm{g}}$ & $0.05 \pm 0.00^{\mathrm{h}}$ & $0.03 \pm 0.00^{\mathrm{g}}$ & $0.15 \pm 0.01^{\mathrm{g}}$ & $0.22 \pm 0.01^{\mathrm{g}}$ \\
\hline
\end{tabular}

${ }^{1)} \mathrm{FM}$, fermented milk; CFM, condensed fermented milk

${ }^{2) a-1}$ Means with the different superscripts in the same column are significantly different by Duncan's multiple range test at $\mathrm{p}<0.05$.

CFM-8의 10개의 센서들 중 6 개인 T30/1, P10/1, P10/2, $\mathrm{P} 40 / 1, \mathrm{~T} 70 / 2, \mathrm{PA} 2$ sensor 감응도가 모두 유의적으로 가장 높았으며(p<0.05), 이로 인해 CFM-8의 향기성분의 강도가 다른 발효유들보다 강하여 PCA plot에서 가장 오른쪽인 PC1 2.35-2.92의 구간에 위치한 것으로 판단된다.

요구르트의 향기성분은 우유에 존재하는 휘발성 물질과 발효에 의해 생성된 전형적인 flavor 성분인 lactic acid, acetaldehyde, diacetyl, acetoin, acetone, and 2-butanone 및 다양한 휘발성물질(carbonyl compounds, alcohols, acids, esters, hydrocarbons, aromatic compounds, sulfur-containing compounds, and heterocyclic compounds)들로 구성되고(31), 당류, 착향료, 과즙 등의 첨가물에 의해 요구르트의 향기성 분에 특이성이 부여된다. 본 연구에서 분석된 요구르트의 성분을 살펴보면 과당, 포도당, 올리고당 등의 당류와 사과, 배, 탱자, 자몽 등의 과즙과, 레몬향, 사과향 및 합성착향료 등이 다양한 농도로 첨가되어, 이 첨가물들이 요구르트의 전형적인 휘발성물질과 함께 시료들의 향기성분패턴에 영 향을 미친 것으로 사료된다.

\section{요 약}

본 연구에서는 시중 유통되는 요구르트인 발효유와 농후 발효유의 $\mathrm{pH}$, 총산, 탁도, 점도와 유기산, 당, CLA 함량
및 향기패턴을 분석하여 그 품질특성을 비교하였다. 발효 유는 농후발효유보다 총산, 탁도, 점도 및 유기산과 CLA 함량이 낮은 경향을 보인 반면, 당 함량은 유의적으로 높게 분석되어 발효유는 농후발효유에 비해 신맛은 약하지만 단맛이 강하고 점도가 낮은 품질특성을 띄었다. 요구르트 의 주요 유기산은 lactic acid으로 citric acid와 acetic acid보 다 각각 8.15-4.72배와 26.83-47.20배 높게 함유되어있고, malic acid와 formic acid는 농후발효유에서만 검출되었으 며, 농후발효유가 발효유보다 lactic acid는 1.47 배, citric acid는 2.53배 많이 함유하고 있다. 주요 당은 sucrose, fructose, lactose, glucose, maltose이고, 특히 발효유에는 sucrose의 함량이 가장 높고 함유범위가 가장 넓었으며, 농 후발효유에는 lactose를 제외한 4 가지 당이 불검출부터 다 양한 범위로 함유되어 있었다. 농후발효유의 조지방과 CLA 함량은 발효유보다 각각 10.8배와 23.6배 높았는데 이는 농후발효유에 사용된 원재료가 발효유에 비해 원유함 량이 높은 반면 발효유는 탈지분유를 사용하는 경향이 높은 데서 비롯된 것으로 사료된다. 전자코를 이용한 향기패턴 분석에서 발효유와 농후발효유의 향기는 5 개의 group으로 clustering 되었고, 그중 농후발효유 1 종과 발효유 1 종은 각 각 다른 그릅으로 분포되어 향기성분이 나머지 요구르트 제품들보다 다른 패턴을 보였다. 분석된 발효유와 농후발 효유는 제조 시 사용된 우유 원재료, 당류 및 과즙 추출물 등의 종류와 첨가량의 차이 등으로 인해 산도, 당도, 점도, 
향기 및 CLA 함량이 다른 것으로 판단되며, 특히 발효유는 sucrose 등의 첨가로 당함량이 현저히 높은 제품도 있지만 무첨가제품도 있어 그 범위가 다양한 것으로 조사되었다. 따라서 시중 유통되는 요구르트는 우유 원재료와 발효균주 및 첨가물의 종류와 함량이 달라 물리화학적 특성 및 관능 적 품질에 차이가 있고, 이는 소비자의 선호도와 구매도에 영향을 미칠 것으로 사료된다.

\section{감사의 글}

본 연구는 2014년도 대구대학교 학술연구비지원으로 수 행되었으며, 이에 감사드립니다.

\section{References}

1. Lee IS, Lee SO, Kim HS (2002) Preparation and quality characteristics of yogurt added with Saururus chinensis (lour.) bail. J Korean Soc Food Sci Nutr, 31, 411-416

2. Lee MJ, Kim KS, Kim YK, Park JC, Kim HS, Choi JS, Kim KJ (2013) Quality characteristics and antioxidant activity of yogurt added with whole barley flour. Korean J Food Sci Technol, 45, 721-726

3. Chung DH (2012) Fermented food a complete collection. Yu Han Publishing Co, Seoul, Korea, p 25-43

4. MFDS (2016) Korean Food Standard Code. Ministry of Food and Drug Safety, Cheongju, Korea

5. Buttriss J (1997) Nutritional properties of fermented milk products. Int J Dairy Technol, 50, 21-27

6. Gambelli L, Manzi P, Panfili G, Vivanti V, Pizzoferrato L (1999) Constituents of nutritional relevance in fermented milk products commercialised in Italy. Food Chem, 66, 353-358

7. Shin JG, Lee JJ, Kim HY, Baek YJ (1991) Studies on the changes of qualities and the sensory evaluation of the stirred yogurt stored at different temperatures. Korean J Dairy Sci, 13, 148-155

8. Ip C, Banni S, Angioni E, Carta G, McGinley J, Thompson HJ, Barbano D, Bauman D (1999) Conjugated linoleic acid-enriched butter fat alters mammary gland morphogenesis and reduces cancer risk in rats. J Nutr, 129, 2135-2142

9. Lee KN, Kritchevsky D, Parizaa MW (1994) conjugated linoleic acid and atherosclerosis in rabbits. Atherosclerosis, 108, 19-25

10. Park YH, Albright KJ, Liu W, Storkson JM, Cook ME,
Pariza MW (1997) Effect of conjugated linoleic acid on body composition in mice. Lipids, 32, 853-858

11. Cook ME, Miller CC, Park Y, Pariza M (1993) Immune modulation by altered nutrient metabolism: nutritional control of immune-induced growth depression. Poult Sci, 72, 1301-1305

12. Chin SF, Liu W, Storkson JM, Ha YL, Pariza MW (1992) Dietary sources of conjugated dienoic isomers of linoleic acid, a newly recognized class of anticarcinogens. J Food Compos Anal, 5, 185-197

13. Lee IS, Paek KS (2003) Preparation and quality characteristics of yogurt added with cultured ginseng. Korean J Food Sci Technol, 35, 235-241

14. Sung JM, Choi HY (2014) Effect of mulberry powder on antioxidant activities and quality characteristics of yogurt. J Korean Soc Food Sci Nutr, 43, 690-697

15. Lee HJ, Pak HO, Lee JM (2006) Fermentation properties of yogurt added with rice bran. Korean J Food Cookery Sci, 22, 488-494

16. Kim MS, Ahn ES, Shin DH (1993) Physico-chemical propertise of commercial yoghurt in Korea. Korean $\mathbf{J}$ Food Sci Technol, 25, 340-344

17. Lee JH, Park HY, Won JI, Park HI, Choi ID, Lee SK, Park JY, Joe DH, Jeon YH, Oh SK, Han SI, Choi HS (2017) Quality characteristics of commercial liquid type yogurt in Korea. Korean J Food Preserv, 24, 865-870

18. MFDS (2016) First Sugars Reduction Comprehensive Plan Briefing. Ministry of Food and Drug Safety, Cheongju, Korea

19. Ko Sj, Jeong SS, Choi Ch, Kim KH (2013) $\mathrm{pH}$ and buffering capacity in some commercial fermented milks. J Korean Soc Dent Hyg, 13, 701-711

20. AOAC (2000) Official Method of Analysis. $17^{\text {th }}$ ed, Association of Official Analytical Chemists, Arlington, VA, USA, Method 962.12

21. Lee JS, Han PJ, Suh KB (1972) Studies on production of modified yoguhrt (soy cream) from soybean milk (I). Korean J Food Sci Technol, 4, 194-199

22. Kosikowski F (1982) Cheese and fermented milk foods. Edwards Brothers Inc, Ann Arbor, MI, USA, p 68-81

23. Kim EA, Lee KW, Park YH, Kwak HS (1992) The study of lactic acid bacteria in yogurt during delivery and storage. Korean J Dairy Sci, 14, 260-268

24. Lim YS, Lee SK (2013) Characteristics of cow milk and goat milk yogurt fermented by Streptococcus thermophilus LFG isolated from kefir. Korean J Food Sci Anim Resour, 33, 787-795 
25. Kim DH, Hwang DG, Chon JW, Kim HS, Kim HS, Song KY, Yim JH, Kim YJ, Kang IB, Lee SK, Seo KH (2015) Simultaneous determination of carbohydrates and organic acids in various cultured dairy foods by high-performance liquid chromatography: a preliminary study. J Milk Sci Biotechnol, 33, 263-269

26. Vidal-valverde C, Martin-villa C, Herranz J (1984) Determination of soluble carbohydrates in yogurts by high performance liquid chromatography. J Dairy Sci, 67, 759-763

27. Lee HK, Kwon YT, Kang HS, Yoon CS, Jeong JH, Kim HK, Kim IH, Chung SH (2004) Conjugated linoleic acid (CLA) contents in commercial yoghurts and production of CLA by commercial dairy starter cultures. J Korean Soc Food Sci Nutr, 33, 1343-1347
28. Yang YM, Noh BS, Hong HK (1999) Prediction of freshness for milk by the portable electronic nose. Food Eng prog, 3, 45-50

29. Labreche S, Bazzo S, Cade S, Chanie E (2005) Shelf life determination by electronic nose: application to milk. Sens Actuator B Chem, 106, 199-206

30. Chung SJ, Lim CR, Noh BS (2008) Understanding the sensory characteristics of various types of milk using descriptive analysis and electronic nose. Korean J Food Sci Technol, 40, 47-55

31. Cheng H (2010) Volatile flavor compounds in yogurt: a review. Crit Rev Food Sci Nutr, 50, 938-950 